\title{
JOURNAL.RU
}

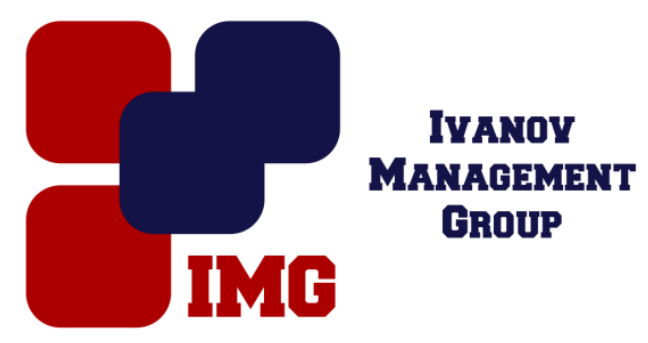

Тавасиев В.X.

Северо-Осетинский государственный университет им.К.Л.Хетагурова Владикавказ, Россия

doi: $10.18411 / \mathrm{lj}-31-07-2017-17$

idsp 000001:1j-31-07-2017-17

\section{Особенности социально-экономического развития Северного Кавказа в XX веке}

\begin{abstract}
Аннотация
В статье рассматриваются особенности социально-экономического развития Северного Кавказа в $\mathrm{XX}$ веке. Проводится сравнительный анализ экономического, социального и демографического развития Республики Северная Осетия-Алания с субъектами Российской Федерации вообще и СевероКавказского федерального округа в частности.

Ключевые слова: экономическое развитие, сравнительный анализ, административно-территориальные образования, территориальная дифференциация, городское население, численность населения, занятость населения.

\section{Abstract}

In the article are analyzed social-economic peculiarities of the North Caucasus development in the XX century. We made a comparative study of economic, social and demographic evolution of the Republic of North Osetia-Alania, Russia territorial units and North Caucasus federal district.

Keywords: economic development, comparative study, administrative- territorial unit, territorial differentiation, urban population, population base, employment of population
\end{abstract}


Практически на протяжении всего XX в. Северный Кавказ рассматривается, прежде всего, как поставщик сельскохозяйственной продукции. Это в значительной мере повлияло на характер и темпы урбанизации, на скорость и завершенность ее процессов.

В 1926 г. в городских поселениях Северного Кавказа проживало 1,7 млн.чел. (19,1\% всех жителей региона), в сельской местности - 7,4 млн.чел. В последующем рост численности городского населения ускорился. За 1926-1938 гг. численность городского населения увеличилась на 76,8\%, а численность сельского - сократилась на 1,9\%. Удельный вес городского населения поднялся с $19,1 \%$ до $29,9 \%$.

За 1939-1958 гг. численность городского населения увеличилась на 61,2\%, а численность сельского - уменьшилась на 9,2\%. В результате удельный вес городских жителей поднялся до 42,8\%. Однако и к 1959 г. Северный Кавказ являлся одним из слабоурбанизированных районов Российской Федерации. Только Волго-Вятский и Центрально-Черноземный районы (27\%) уступали Северо-Кавказскому по доле городских жителей.

С 1959 г. численность городского населения Северного Кавказа стала расти быстрее, чем в целом по Российской Федерации. На Северном Кавказе темпы роста числа городских поселений в 1959-1988 гг. были выше, чем в среднем по Российской Федерации. Особенно быстро росло число городов, которые возникали чаще всего путем преобразования крупных сельских поселений в городские. Если средняя людность городских поселений Российской Федерации росла, то на Северном Кавказе она снижалась.

Таким образом, Северный Кавказ выделяется на фоне средних показателей в целом по Российской Федерации низким удельным весом городского населения, при высокой средней людности городских поселений и высокой их густоте (при повышенной доле городов). Кажущаяся противоречивость объясняется весьма просто: при удельном весе территории в 2,1\%, Северный Кавказ концентрировал 9,1\% городского населения РФ. Относительно Северной Осетии можно отметить, что на фоне Северного Кавказа она выделяется высоким удельным весом и высокой густотой городских поселений. При удельном весе территории республики в общей площади СКЭР в 2,25\%, Северная Осетия концентрирует 4,67\% всего городского населения экономического района. 
К 1959 г. Северный Кавказ концентрировал 11,9\% сельского населения России, а к 1989 г. - уже 18,3\%16. Таким образом, налицо все большая концентрация сельского населения России на Северном Кавказе [2].

За 1959-1988 гг. городское население Северо-Кавказского экономического района (СКЭР) увеличилось на 91,1\%, в то время как в целом по Российской Федерации - на 75,2\%. Особенно быстро росло городское население в 1959 1969 гг., когда оно выросло в Российской Федерации на 31,4\%, а на Северном Кавказе - на 43,2\%. В среднем за год городское население Российской Федерации росло на 2,85\%, а Северного Кавказа — на 3,93\%. В 1970-1978 гг. темпы прироста численности городского населения на Северном Кавказе снизились почти вдвое и стали чуть ниже, чем в целом по России. В 1979-1988 гг. темпы прироста численности городского населения стали еще более низкими. Однако северокавказские темпы прироста вновь стали несколько выше общероссийских [1].

Численность сельского населения в Российской Федерации сокращалась на протяжении всего периода 1926-1988 гг. На Северном Кавказе сокращение численности сельского населения наблюдалось не всегда. Так, в 1959-1969 и 1979-1988 гг. наблюдалось увеличение численности сельского населения. Да и в другие периоды темпы сокращения были значительно ниже, чем в целом по Российской Федерации.

1. Атаев А.В., Тавасиев Г.В. Социально-экономические особенности РСО-А в середине ХХ века// Тенденции науки и образования в современном мире. - 2016. - №21-2. - С.24-25.

2. Тавасиев В.Х., Тавасиев Г.В. Социально-экологические проблемы в Республике Северная Осетия-Алания// Вестник университета (Государственный университет управления), №8. - Москва, 2015. - С.233-238. 